\title{
PENENTUAN TINGKAT KANDUNGAN AMONIAK, NITRIT, DAN NITRAT PADA REMBESAN SAMPAH LOKASI PEMBUANGAN AKHIR (LPA) AIR DINGIN KOTA PADANG
}

\author{
Zilfa, Zulfarman, dan Hariyanti \\ Laboratorium Kimia Terapan FMIPA Universitas Andalas \\ Email : zilfa_58@yahoo.com
}

\begin{abstract}
Determination of amoniac, nitrite, and nitrate content in seepage waste water in landfill area in cold water, Padang have been done using spectrophotometric method. Sample took from sequencing of seepage waste water treatment process. The results showed that the ammonia, nitrite, and nitrate content in seepage waste water were 137.612 to $400.298 \mathrm{mg} / \mathrm{L}, 0.34$ to $0.756 \mathrm{mg} / \mathrm{L}$, and 0.682 to $5.842 \mathrm{mg} / \mathrm{L}$, respectively. The differences of ammonia, nitrite, and nitrate content in seepage waste water and ammonia and nitrite contents tend to decrease while the nitrate content tends to increase. The rate of ammonia degradation in water seepage was different for each sampling place where the rate of degradation was greatest in seepage water waste treatment II. This degradation is expected to reduce the level of pollution on the environment.
\end{abstract}

Keywords : amoniac, nitrite, nitrate, landfill

\section{PENDAHULUAN}

Lokasi Pembuangan Akhir (LPA) Air Dingin merupakan suatu tempat pembuangan sampah akhir yang terdapat di Lubuk Minturun Kota Padang. LPA yang didirikan sejak tahun 1989 ini menampung sampah dari kota Padang dan sekitarnya. Pada lokasi ini dilakukan sistem pengolahan sampah dan air rembesan sampah supaya tidak mencemari lingkungan sekitarnya ${ }^{[1]}$.

Pada awal didirikan, sistem pengolahan sampah yang digunakan pada LPA ini yaitu system sanitary landfill dimana sampah dibuang ke dalam galian tanah kemudian ditutup dengan tanah dan dibeton. Tetapi sejak 8 tahun terakhir, sistem pengolahan sampah diganti dengan system open dumping dimana sampah didatarkan di atas lahan terbuka dan ditimbun dengan $\operatorname{tanah}^{[2]}$.

Pengolahan air rembesan sampah yang digunakan adalah pengolahan dengan pembuatan bak penampungan, bak kontrol dan kolam-kolam pengolahan sampah. Prinsip pengolahannya adalah dekomposisi air rembesan sampah dengan bantuan mikroba yang ada dalam air tersebut.

Air rembesan sampah merupakan limbah yang sangat berbahaya bagi lingkungan sekitarnya baik manusia, hewan, dan tumbuhan. Air rembesan sampah ini mengandung bermacam-macam zat organik dan anorganik, sebagian ada yang berguna bagi lingkungan dan sebagian lagi memiliki dampak negatif bagi lingkungan ${ }^{[1-3]}$.

Diantara zat yang ada pada air rembesan sampah yang memiliki dampak negatif bagi lingkungan adalah zat nitrogen organik, dimana nitrogen organik dengan bantuan bakteri akan mengalami penguraian nitrogen organik yang merupakan bahan-bahan yang mengandung protein menjadi amoniak ${ }^{[4,5]}$.

Amoniak di perairan akan mengakibatkan kandungan oksigen dalam air semakin menurun karena oksigen yang ada digunakan untuk mengoksidasi amoniak menjadi nitrit dan mengoksidasi nitrit menjadi nitrat. Apabila oksigen menurun, maka biota air akan kekurangan oksigen dan mati ${ }^{[6]}$. Disamping itu, nitrit dan nitrat yang 
dihasilkan bisa merembes ke badan tanah sehingga mengkontaminasi air sumur yang digunakan oleh manusia ${ }^{[7]}$. Pengoksidasian amoniak dengan adanya oksigen dan bakteri menjadi nitrit dan nitrit dioksidasi menjadi nitrat merupakan degradasi amoniak di perairan $^{[8,9]}$.

Untuk memperoleh kejelasan ilmiah fenomena di atas perlu dilakukan kajian kuantitatif tentang kandungan amoniak, nitrit, dan nitrat pada air rembesan sampah sesuai dengan urutan pengolahan air rembesan sampah di LPA Air Dingin Kota Padang. Dari kandungan amoniak, nitrit, dan nitrat yang diperoleh dapat diketahui tingkat degradasi amoniak ${ }^{[6,10]}$.

\section{METODOLOGI PENELITIAN}

\section{Pengambilan sampel}

\section{Lokasi pengambilan sampel}

Air rembesan sampah diambil dibeberapa titik pada sistem pengolahan air rembesan sampah di LPA Air Dingin Padang.

\section{Titik pengambilan sampel}

Pengambilan sampel dilakukan pada tempattempat sebagai berikut:

a. Air rembesan sampah pada system open dumping (R0).

b. Air rembesan sampah pada pipa I yang berasal dari air rembesan sampah dari system open dumping ke bak kontrol (R1).

c. Air rembesan pada pipa II yang berasal dari air rembesan sampah system sanitary landfill ke bak kontrol (R2).

d. Air rembesan sampah pada bak kontrol (R3).

e. Air rembesan sampah pada kolam pengolahan I (R4).

f. Air rembesan sampah pada kolom pengolahan II (R5).

g. Air rembesan sampah pada kolam pengolahan III (R6).

\section{Kondisi Kolam}

Kolam Pengolahan I:

Kedalaman $3 \mathrm{~m}$, posisi pipa masuk $3 \mathrm{~m}$ dari dasar kolam, posisi pipa keluar 2,5 $\mathrm{m}$ dari dasar kolam, dan luas $30 \mathrm{~m}$ x $8 \mathrm{~m}$.

Kolam Pengolahan II:

Kedalaman $3 \mathrm{~m}$, posisi pipa masuk $3 \mathrm{~m}$ dari dasar kolam, posisi pipa keluar 2,5 m dari dasar kolam, dan luas $33 \mathrm{~m}$ x $21 \mathrm{~m}$.

Kolam pengolahan III:

Kedalaman $3 \mathrm{~m}$, posisi pipa masuk 2,5 $\mathrm{m}$ dari dasar kolam, posisi pipa keluar 2,5 m dari dasar kolam, dan luas $30 \mathrm{~m}$ x $20 \mathrm{~m}$.

\section{Alat dan Bahan}

Peralatan yang digunakan pada penelitian ini adalah seperangkat peralatan spektrofotometer Genesys 20, labu ukur, pipet gondok, gelas piala, gelas ukur, corong, batang pengaduk, erlenmeyer, kaca arloji, oven listrik, neraca analitik.

Bahan yang digunakan meliputi sampel air rembesan sampah pada beberapa titik, $\mathrm{HgI}_{2}$, $\mathrm{KI}, \mathrm{NH}_{4} \mathrm{Cl}, \mathrm{NaOH}, \quad \mathrm{NaNO}_{2}, \quad \mathrm{KNO}_{3}$, kloroform, asam sulfanilat, asam asetat glasial, N-(1-naftil) etilen diamin diklorida, Brusin sulfat, $\mathrm{HCl}$ pekat, $\mathrm{H}_{2} \mathrm{SO}_{4}$, dan air suling.

\section{Prosedur Kerja}

\section{Penentuan parameter air}

\section{Penentuan amoniak}

Ke dalam masing-masing $50 \mathrm{~mL}$ larutan standar amoniak $0 ; 0,2 ; 0,4 ; 0,6 ; 0,8 ; 1,0$ $\mathrm{mg} / \mathrm{L}$ ditambahkan $2 \mathrm{~mL}$ reagen Nessler, lalu didiamkan kira-kira 10 menit. Dilakukan prosedur yang serupa pada sampel. Dimasukkan beberapa $\mathrm{mL}$ larutan ke dalam kuvet spektrofotometer dan diukur serapannya pada panjang gelombang $405 \mathrm{~nm}$. Dihitung konsentrasi amoniak dengan menggunakan kurva kalibrasi standar. 


\section{Penentuan nitrit}

Dipipet $5 \mathrm{~mL}$ masing-masing larutan standar nitrit $0 ; 0,05 ; 0,10 ; 0,20 ; 0,30 ; 0,40 ; 0,50$ $\mathrm{mg} / \mathrm{L}$ dan dimasukkan ke botol vial. Ditambahkan $1 \mathrm{~mL}$ reagen Saltzman, didiamkan sekitar 30 menit. Dilakukan prosedur serupa terhadap sampel. Dimasukan beberapa $\mathrm{mL}$ larutan ke dalam kuvet spektrofotometer dan diukur serapannya pada panjang gelombang $543 \mathrm{~nm}$. Dihitung konsentrasi nitrit sampel dengan menggunakan kurva kalibrasi standar.

\section{Penentuan nitrat}

Dipipet $5 \mathrm{~mL}$ masing-masing larutan standar nitrit $0 ; 0,5 ; 1,0 ; 2,0 ; 3,0 ; 4,0 \mathrm{mg} / \mathrm{L}$ dan dimasukkan ke botol vial. Ditambahkan 10 $\mathrm{mL} \mathrm{H}_{2} \mathrm{SO}_{4}$ pekat perlahan-lahan ke dalam masing-masing larutan standar, dikocok. Ditambahkan 5 tetes reagen Brusinsulfanilat. Didinginkan selama 5-7 menit. Dilakukan cara yang sama pada sampel. Dimasukan beberapa $\mathrm{mL}$ larutan ke dalam kuvet spektrofotometer dan diukur serapannya pada panjang gelombang $410 \mathrm{~nm}$. Dihitung konsentrasi nitrat sampel dengan menggunakan kurva kalibrasi standar.

\section{HASIL DAN PEMBAHASAN}

\section{Amoniak}

Hasil penentuan amoniak menunjukkan bahwa adanya perubahan tingkat kandungan amoniak pada tiap titik sampel air rembesan sampah LPA Air Dingin Padang. Perubahan tingkat kandungan amoniak dapat dilihat pada Gambar 1.

Dari Gambar 1, grafik kandungan amoniak pada tiap titik sampel air rembesan sampah LPA Air Dingin Padang menunjukkan bahwa perubahan tingkat kandungan amoniak sangat nyata untuk setiap titik pengambilan sampel. Perubahan tingkat kandungan amoniak dapat dilihat dari penurunan kandungan amoniak dari lokasi R0 ke R1, R0 ke R2, dan R3 ke R6.

Lokasi R0 merupakan lokasi air sampah pada pengolahan sampah secara Open Dumping, R1 merupakan lokasi air rembesan sampah yang berasal langsung dari sistem pengolahan sampah secara Open dumping sedangkan lokasi R2 merupakan lokasi air sampah pada pengolahan sampah secara sanitary landfill. R3 sampai R6 merupakan lokasi air dari sistem pengolahan air rembesan sampah.

Kandungan amoniak pada lokasi R0 merupakan kandungan amoniak tertinggi yaitu $400 \mathrm{mg} / \mathrm{L}$. Pada lokasi ini, air sampahnya berada pada tempat pengolahan sampah secara open dumping. Pada lokasi R1 mengalami penurunan kandungan amoniak karena air sampahnya berasal dari pengaliran air lokasi R0 yang telah mengalami oksidasi oleh bakteri aerob.

Perbedaan kandungan amoniak R1 dan R2 disebabkan oleh adanya perbedaan sumber air rembesan sampahnya. Dimana, R1 merupakan air rembesan sampah dari system open dumping, sedangkan R2 merupakan air rembesan sampah dari system sanitary landfill.

Penurunan kandungan amoniak pada R3 hingga R6 disebabkan oleh adanya pengoksidasian amoniak secara bertahap oleh bakteri aerob ${ }^{[5-7]}$. Sehingga air pada lokasi R6 merupakan air yang memiliki kandungan amoniak terendah yaitu $137 \mathrm{mg} / \mathrm{L}$.

\section{Nitrit}

Hasil penentuan nitrit menunjukkan bahwa adanya perubahan tingkat kandungan nitrit pada tiap titik sampel air rendaman sampah LPA Air Dingin Padang. Kandungan nitrit pada tiap titik sampel dapat dilihat pada Gambar 2. 




$R 5,157,5133.612$



Titik Pengambilan Sampel

Gambar 1. Kandungan amoniak pada tiap titik sampel air rembesan sampah LPA Air Dingin Padang

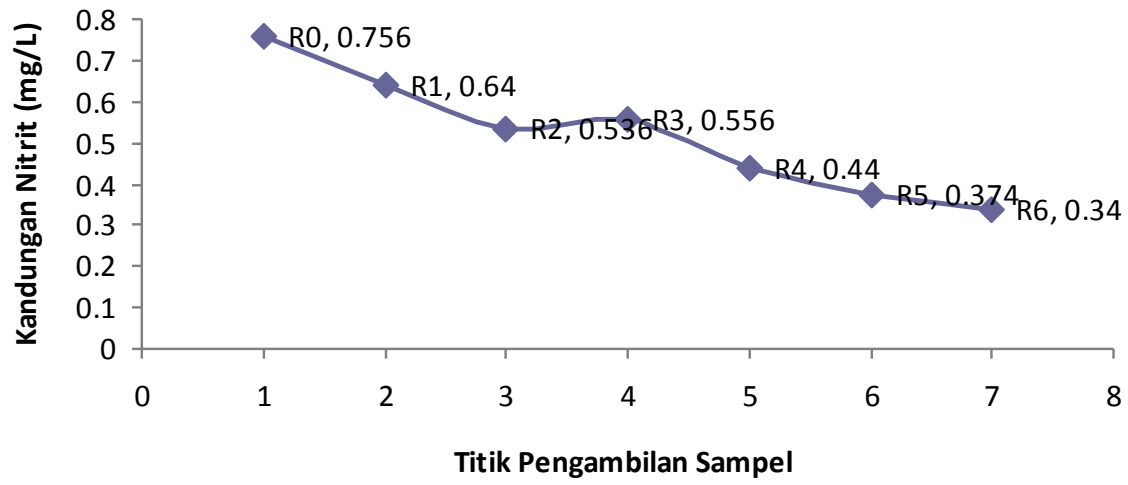

Gambar 2. Kandungan nitrit pada tiap titik sampel air rembesan sampah LPA Air Dingin Padang

Dari Gambar 2, grafik kandungan nitrit pada tiap titik sampel air rembesan sampah LPA Air Dingin Padang menunjukkan bahwa perubahan tingkat kandungan nitrit diketahui dengan adanya penurunan kandungan nitrit dari lokasi R0 ke R1, R0 ke R2, dan R3 sampai R6. Dimana air pada lokasi R0 memiliki kandungan nitrit tertinggi yaitu 0,75 $\mathrm{mg} / \mathrm{L}$ dan air pada lokasi R6 memiliki kandungan nitrit terendah yaitu $0,34 \mathrm{mg} / \mathrm{K}$. sedangkan kandungan nitrit pada air lokasi $\mathrm{R} 2$ adalah $0,53 \mathrm{mg} / \mathrm{L}$.

Penurunan kandungan nitrit dari R0 ke R1 tidak terlalu tajam. Hal ini disebabkan karena lokasi R0 ke R1 merupakan lokasi air sampah terbuka yang mana terjadinya penguapan amoniak ke udara dan pengoksidasian amoniak oleh bakteri menjadi nitrit dengan kadar oksigen air sampah yang banyak dan nitrit yang terbentuk akan cepat teroksidasi menjadi nitrat ${ }^{[6]}$.
Tingginya kandungan nitrit pada R0 dan R1 dibandingkan pada R2 disebabkan oleh perbedaan proses pengolahannya. Dimana, lokasi R0 dan R1 merupakan lokasi terbuka yang kaya dengan oksigen sehingga memudahkan proses pengoksidasian, sedangkan pada R2 yang merupakan lokasi tertutup yang memiliki kadar oksigen air sampah yang rendah sehingga sedikitnya proses pengoksidasian.

Penurunan kandungan nitrit dari R3 sampai R6 terjadi karena adanya proses pengoksidasian amoniak dengan bantuan bakteri dan oksigen tetapi jumLah nitrit yang diperoleh tidak banyak karena nitrit yang dihasilkan akan cepat mengalami proses oksidasi oleh bakteri aerob menjadi nitrat ${ }^{[6-8]}$.

\section{Nitrat}

Hasil penentuan nitrat menunjukkan bahwa terjadinya perubahan tingkat kandungan 
nitrat pada tiap titik sampel air rembesan sampah LPA Air Dingin Padang. Perubahan tingkat kandungan nitrat dapat dilihat pada Gambar 3.

Dari Gambar 3, grafik kandungan nitrat pada tiap titik sampel air rembesan sampah LPA Air Dingin Padang menunjukkan bahwa perubahan tingkat kandungan nitrat sangat nyata untuk setiap titik pengambilan sampel. Perubahan tingkat kandungan nitrat dapat dilihat dengan adanya kenaikan kandungan nitrat dari R0 ke R1, R0 ke R2, dan R3 hingga R6. Kenaikan kandungan nitrat ini disebabkan karena adanya pengoksidasian nitrit menjadi nitrat oleh bakteri aerob ${ }^{[6,8]}$.

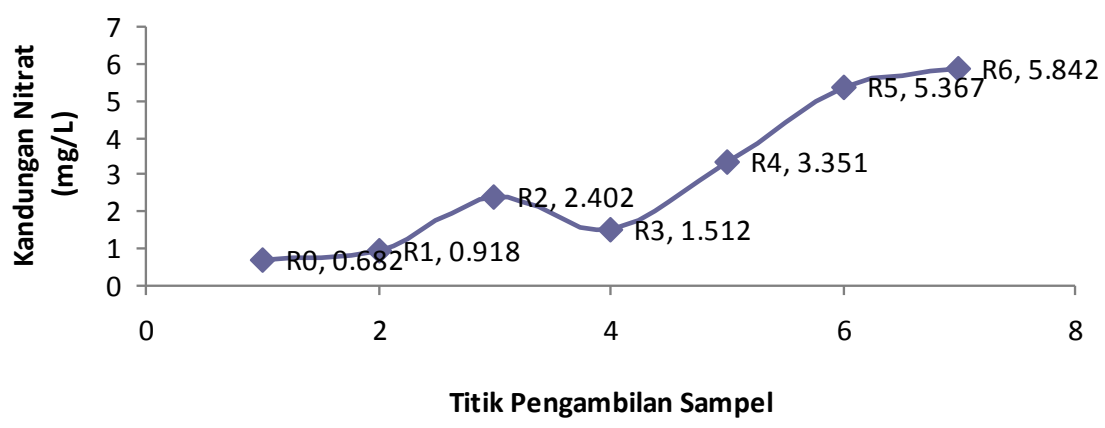

Gambar 3. Kandungan nitrat pada tiap titik sampel air rembesan sampah LPA Air dingin Padang.

Kandungan nitrat tertinggi terdapat pada air lokasi R6 sebesar 5,84 mg/L karena air pada kolam pengolahan III sudah mengalami penguraian air rembesan sampah secara aerob yang cukup lama dibanding pengolahan air lainnya. Sedangkan pada R0 yang memiliki kandungan nitrat yang terendah yaitu $0,68 \mathrm{mg} / \mathrm{L}$.

Kandungan nitrat pada air rembesan dari sampah system sanitary landfill yaitu lokasi R2 sebesar 2,40 mg/L. Hal ini terjadi karena kadar oksigen air pada lokasi lainnya sehingga tingkat kandungan nitratnya tidak terlalu tinggi.

\section{Kandungan Amoniak, Nitrit dan Nitrat pada Tiap Titik Sampel}

Usaha mengetahui tingkat degradasi (penguraian) amoniak pada berbagai bahagian LPA Air Dingin Padang dilihat dari kandungan amoniak, nitrit, dan nitrat pada tiap titik pengambilan sampel di LPA Air Dingin Padang. Kandungan amoniak, nitrit, dan nitrat pada tiap titik pengambilan sampel dapat dilihat pada Gambar 4.

Dari Gambar 4, grafik kandungan amoniak, nitrit dan nitrat pada tiap titik sampel air rembesan sampah LPA Air Dingin Padang menunjukkan bahwa kandungan amoniak lebih besar dibanding kandungan nitrit dan nitrat. Hal ini disebabkan karena adanya penguraian sampah khususnya sampah yang mengandung nitrogen organik menghasilkan produk utama berupa amoniak, sebahagian amoniak mengalami oksidasi menjadi nitrit dan nitrat ${ }^{[6,7]}$. Rendahnya kandungan nitrit dan nitrat juga diduga karena penggunaan nitrit dan nitrat oleh bakteri denitrifikasi ${ }^{[6]}$.

Dari Gambar 4, tingkat degradasi amoniak air rembesan sampah ditunjukkan oleh adanya perbedaan tingkat kandungan amoniak, nitrit, dan nitrat pada setiap tahapan pengolahan air rembesan sampah. Data di atas menunjukkan bahwa semakin lama air sampah mengalami proses pengolahan maka semakin tinggi tingkat degradasi amoniaknya. Sehingga, kandungan amoniak pada air rembesan sampah menunjukkan pengurangan ${ }^{[5]}$.

Hal di atas juga terjadi pada R2, dimana air yang berasal dari sistem pengolahan sanitary landfill yang pengolahannya sudah puluhan silam secara tertutup dan rendahnya kadar oksigen, maka penguraian yang terjadi lebih banyak secara anaerob daripada aerob sehingga kandungan amoniak dan nitritnya 




Gambar 4. Kandungan amoniak, nitrit dan nitrat pada tiap titik sampel air rembesan sampah LPA Air Dingin Padang

lebih rendah dari pada kandungan amoniak dan nitrit pada R0 dan R1. Tingkat degradasi amoniak pada sistem pengolahan air rembesan sampah yang paling besar terjadi pada lokasi R5 yaitu lokasi air kolam pengolahan II. Hal ini terjadi karena proses penguraian air sumpah pada R5 merupakan air rembesan yang mengalami pengoksidasian aerob yang tinggi dibandingkan lokasi pengolahan air rembesan sampah lainnya.

\section{KESIMPULAN}

Berdasarkan penelitian yang telah dilakukan, maka dapat disimpulkan bahwa : kandungan amoniak air rembesan sampah berkisar antara 137,612 - 400,298 mg/L dimana kandungan tertinggi pada air rembesan sampah dari system open dumping. Kandungan nitrit berkisar antara $0,34-0,756 \mathrm{mg} / \mathrm{L}$ dimana kandungan tertingginya pada air rembesan sampah dari system open dumping, sedangkan kandungan tertingginya pada air rembesan sampah kolam pengolahan III

Kandungan amoniak, nitrit, dan nitrat mengalami perubahan tingkat kandungan pada setiap proses pengolahan air rembesan sampah dimana tingkat kandungan amoniak dan nitrit cenderung mengalami penurunan sedangkan tingkat kandungan nitrat cenderung mengalami kenaikan. Tingkat degradasi amoniak pada air rembesan sampah berbeda untuk setiap titik pengambilan sampel, dimana tingkat degradasi paling besar terjadi pada lokasi kolam pengolahan. Dengan terdegradasinya amoniak diharapkan dapat mengurangi tingkat pencemaran terhadap lingkungan.

\section{DAFTAR PUSTAKA}

1. R. Ahmad, Kimia lingkungan, ANDI, Yokyakarta, 93-138, (2004).

2. R. Suddrajat, Mengelola sampah kota, Penebar Swadaya, Depok, 5-12, (2006).

3. C. T. Sutrisno, Teknologi penyediaan air bersih, Usaha Nasional Surabaya 184-216, (1987).

4. E. S. Manahan, Environmental, chemistry, $6^{\text {th }}$, ed, Lewis Publisher. Florida, 160-165, 1994.

5. Zulkifli dan Elfiyeldi, Kandungan zat hara dalam air poros dan air permukaan padang lamun bintan timur riau, J. Natur Indonesia., 5(2), 139-144, (2003).

6. D. W. Cornell, dan J. M. Gregory, Kimia dan ekotoksikologi pencemaran Universitas Indonesia, 2006.

7. B. Thomson, Nitrates and nitrites dietary exposure and risk assessment, Institute of environmental Sciens \& Research Limited, Christcherch Science Centre, New Zealand, 2004.

8. A. T. Sastrawijaya, Pencemaran lingkungan, Rineka Putra Jakarta, 2000.

9. A. R. Day dan L. A. Undewood, Analisa kuantitatif, ed, VI, Erlangga, Jakarta, 2002, 396-400.

10. Basset, Buku Ajar Vogel: Kimia Analisis Kuantitatif Anorganik, Penerjemah, A. Hayana, dkk, EGC, Jakarta, 1994, 850880. 